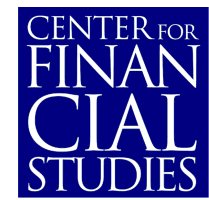

No. $2002 / 15$

\title{
Activist Stabilization Policy and Inflation: The Taylor Rule in the 1970s
}

Athanasios Orphanides

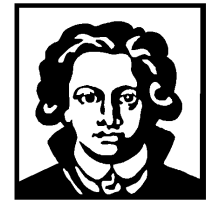

Center for Financial Studies 


\title{
Activist Stabilization Policy and Inflation: The Taylor Rule in the 1970s
}

\author{
Athanasios Orphanides*
}

November 2002

\begin{abstract}
:
A number of recent studies have suggested that activist stabilization policy rules responding to inflation and the output gap can attain simultaneously a low and stable rate of inflation as well as a high degree of economic stability. The foremost example of such a strategy is the policy rule proposed by Taylor (1993). In this paper, I demonstrate that the policy settings that would have been suggested by this rule during the 1970s, based on real-time data published by the U.S. Commerce Department, do not greatly differ from actual policy during this period. To the extent macroeconomic outcomes during this period are considered unfavorable, this raises questions regarding the usefulness of this strategy for monetary policy. To the extent the Taylor rule is believed to provide a reasonable guide to monetary policy, this finding raises questions regarding earlier critiques of monetary policy during the 1970s.
\end{abstract}

JEL Classification: E3, E52, E58

Keywords: Great Inflation, Taylor rule, output gap, real-time data.

Correspondence: Athanasios Orphanides, Division of Monetary Affairs, Board of Governors of the Federal Reserve System, Washington, D.C. 20551, USA phone: (202) 452-2654, Email: athanasios.orphanides@ frb.gov. Athanasios Orphanides is also a research fellow in the programme area "Central Banking and Monetary Economics" of the Center for Financial Studies, Taunusanlage 6, D-60329 Frankfurt/Main, Germany.

I would like to thank David Lindsey, Chris Plantier, Richard Porter, Charles Steindel, Diana Weymark, as well as participants at presentations at the Reserve Bank of New Zealand, the Reserve Bank of Australia, the Econometric Society, and the Conference on Monetary Policy and the Labor Market in Honor of James Tobin at the New School University for helpful discussions and comments on earlier drafts. The opinions expressed are those of the author and do not necessarily reflect views of the Board of Governors of the Federal Reserve System. 


\section{Introduction}

There is widespread agreement that the objective of monetary policy in the United States over the past several decades has been the pursuit of price stability and maximum sustainable growth over time. Recent studies have suggested that activist stabilization policy rules that respond to inflation and the level of economic activity can achieve these objectives and attain both a low and stable rate of inflation as well as a high degree of economic stability. ${ }^{1}$ A critical aspect that differentiates these rules from alternative guides to policy, such as policies that concentrate on inflation or stable money and nominal income growth, is the emphasis they place on the level of economic activity in relation to a concept of the economy's potential - that is the "output gap" or the related "unemployment gap." A prominent example of such a strategy is the policy rule proposed by Taylor (1993). Unfortunately, as a practical matter, the informational requirements of implementing these activist policies, especially the measurement of the "output gap" or "unemployment gap" present substantial difficulties. As a result, activist stabilization strategies that might appear promising when these difficulties are ignored may instead prove counterproductive when implemented in practice.

This observation is not new. Indeed, it is at the very center of the monetarist criticism regarding activist control of the economy - the old "monetarists" versus "activists" debate. At least since the late 1940s, Milton Friedman and later others including Allan Meltzer and Karl Brunner warned that since the reliable information required to make activist countercyclical policies useful is not typically available, such policies should be avoided. Instead, they favored simple policy rules such as a constant rate of money growth which do not require such concepts as the output gap. (See e.g. Friedman, 1947 and 1968, Brunner, 1985 and Meltzer, 1987.) This debate, needless to say, was not satisfactorily resolved by the 1970s or even later.

As is well known, macroeconomic policy in the United States during the 1960s and 1970s appeared to have been guided by activist stabilization objectives. The "New Eco-

\footnotetext{
${ }^{1}$ Clarida, Gali and Gertler (1999), McCallum (1999) and Taylor (1998) provide surveys of the recent monetary policy rules literature. Fischer (1990) reviews earlier contributions.
} 
nomics" which was arguably introduced in 1961 with the first Kennedy Council of Economic Advisers - Walter Heller, Kermit Gordon, and James Tobin - was at first remarkably successful in engineering a period of great prosperity in the Nation. ${ }^{2}$ But this success did not last. By the end of the 1960s (especially after Heller, Gordon and Tobin, and the remarkable economic team they had originally assembled was no longer formulating policy), prosperity was tempered by worsening inflation. Although macroeconomic policymakers apparently attempted to keep up with the earlier success, and continued to rely for guidance on the "output gaps" and "unemployment gaps" that had proven useful in the early 1960s, inflation became the dominant and worsening problem. Indeed, the Great Inflation which started in the late 1960s and intensified during the 1970s, is generally viewed as one of the most significant failures of monetary policy since the founding of the Federal Reserve. ${ }^{3}$

In light of this experience, it is instructive to examine whether the recently proposed activist monetary policy rules that emphasize policy reactions to the level of economic activity relative to the economy's potential would have provided better guidance to policymakers during that period relative to the framework that guided policy at the time. A detailed recent evaluation along these lines has been provided by Taylor (1999b). Taylor examined the policy prescriptions from two baseline rules for the federal funds rate, the rule he proposed in 1993 and an alternative placing greater emphasis on the output gap. For the 1970s, Taylor demonstrated that actual policy was systematically easier than what his baseline rules would have prescribed. He interpreted the results as suggesting that the Taylor rule would have guided policy away from the inflationary policies of the 1970s. Taylor's favorable interpretation, however, is based on information that was not available to policymakers when policy decisions were made. As a result, this analysis merely demonstrates that the Taylor rule would have avoided the inflationary outcomes of the 1970s if policy could be set with the benefit of hindsight. Arguably, this exercise does not adequately address whether this rule is robust to the informational problems that are at the center of the monetarist

\footnotetext{
${ }^{2}$ Tobin $(1966,1972)$ provides informative reviews of the early debates and the economic outcomes of the period. Heller, Gordon and Tobin (1961) provide an early outline, and the classic 1962 Economic Report of the President reviews the original plans, ideas and their rationale.

${ }^{3}$ De Long (1997), Hetzel (1998) and Meyer (1999) provide extensive analysis and bibliographies. Eckstein (1978) and Blinder (1979) provide enlightening contemporaneous analyses.
} 
critique of activist policies.

In this paper, I revisit this issue by examining the policy prescriptions that would have been suggested by the Taylor rule in real time during the 1970s. To this end, I rely exclusively on data that were available to the general public, drawing extensively from publications of the U. S. Commerce Department. The resulting reconstruction of the Taylor rule suggests that the prescriptions obtained by the rule without the benefit of hindsight do not greatly differ from the actual setting of the federal funds rate during the 1970s. This outcome suggests that the Taylor rule is perhaps as susceptible to informational problems as other activist stabilization strategies that attracted criticism from monetarists over the past half century. The analysis also indicates that policy frameworks such as the Taylor rule, do not appear to be more "rule-like" than similar policies that others, for example Tobin, termed "discretionary." Indeed, on the one hand, Taylor (1993) stressed that an element of discretion is an important part of the rule-based policy framework he proposed. On the other hand, the description of discretionary policy provided by Tobin (1983) maintains some of the important attributes of Taylor's rule-like approach. ${ }^{4}$ It is therefore hard to draw a clear distinction between "rules" and "discretion" in this case. In the end, my analysis suggests that the unfavorable macroeconomic outcomes of the 1970s do not fundamentally reflect differences in the existing framework from Taylor's rule-based framework. Rather, the analysis identifies misperceptions regarding the state of the economy in conjunction with an activist stabilization objective as the important factors leading to the inflationary experience of the 1970s.

\footnotetext{
${ }^{4}$ The following exchange of views, from Wessel (2000), is informative regarding the terminological difficulty:

James Tobin, a Nobel laureate in the nonrules camp, questions if Mr. Taylor preaches what he claims to preach: "Starting from the side of the debate opposite to mine, he seems to arrive at the same place. Follow the spirit, the intent, of a rule, he says, and do not be bound by a particular quantitative formula." Mr. Taylor responds: "What I would like to do is get rules to $80 \%$ of the decision. That would be enormous progress.

Tobin (1998) provides a detailed exposition of the usefulness of the Taylor-rule framework and its relationship to his own views on policy strategy.
} 


\section{An Overview of the Taylor Rule}

The Taylor rule originated in a collection of studies examining the comparative performance of alternative simple interest rate policy rules across a variety of different models (Bryant, Hooper and Mann, 1993). A particularly promising rule in those studies prescribed that the Federal Reserve should set policy so that the deviation of the short-term nominal interest rate, $R$, from a baseline equilibrium value, $R^{*}$, respond linearly to the deviation of inflation, $\pi$ from its desired target, $\pi^{*}$, and to the output gap, $y$.

$$
R-R^{*}=\theta\left(\pi-\pi^{*}\right)+\theta y
$$

Taylor (1993) proposed a particular parameterization of this rule that has attracted considerable attention. He set the sum of actual inflation and the equilibrium short-term real interest rate, $r^{*}$, as a proxy for $R^{*}$, and used the values $r^{*}=\pi^{*}=2$ and $\theta=1 / 2$. (Throughout, the interest and inflation rates are stated in percent annual rates and the output gap in percent.) This parameterization attracted attention as a guide to policy decisions because in addition to its encouraging performance in alternative models, as reported in Bryant, Hooper and Mann (1993) and several subsequent studies, it also appeared to accurately describe actual policy decisions in the 1987-1992 period that Taylor had originally examined. Since monetary policy over this period was considered successful, the confluence of the two results suggested that the Taylor rule may represent a useful and reliable guide for monetary policy decisions. In recent years, prescriptions from a Taylor rule have been regularly provided to Federal Open Market Committee (FOMC) members. Further, since January 1998 the Federal Reserve Bank of St Louis has published monthly updates of prescriptions from the Taylor rule in the publication Monetary Trends.

As is well known, despite its apparent simplicity, implementation of the Taylor rule in practice is not straightforward (see e.g. Orphanides, 1998, 2001). In addition to the parameters specified above (including the difficult to determine equilibrium real interest rate), implementation requires an exact definition of the inflation and output gap inputs to the rule. As is common practice in this literature, for his analysis Taylor employed the latest vintage of historical data available. He used the log difference in the GDP deflator 
over four quarters ending with the current quarter for inflation. For the output gap, he adopted the log difference between actual real output in the current quarter and a smooth trend estimate of potential output. An immediate difficulty, emphasized by McCallum (1994), is that rules that rely on within-quarter reactions to data about that quarter are not operational since the data needed for the rule are not available within the quarter. As a result, in practice the Taylor rule has been operationalized either by using within-quarter forecasts or by specifying that policy react to inflation and the output gap for the previous quarter. In model-based policy evaluation studies both approaches have been extensively examined with similar results. (See e.g. Levin, Wieland and Williams, 1999, and McCallum and Nelson, 1999.) For policy prescriptions that rely exclusively on data available to the public, only the latter option applies. For instance, the Taylor rule published by the Federal Reserve Bank of St Louis employs this one-quarter-lag timing. To focus attention on the Taylor rule as could be applied with data available to the general public I also adopt this timing below.

A second difficulty, emphasized by Orphanides $(2001,2002)$, is that the data and key assumptions employed to construct the rule change over time. These changes reflect a number of sources, such as conceptual changes in the definitions of actual output, potential output and price indexes, reestimation of historical time series (including seasonal definitions), incorporation of previously incomplete or unavailable historical data and the evolution of underlying modeling practices. As a consequence of this difficulty, historical examination of the Taylor rule requires close attention to the vintage of data employed. A reconstruction based on current data can provide information regarding the setting of a rule that a policymaker could have achieved with the benefit of hindsight but not regarding the setting of a rule that could have been actually implemented, nor the setting of a rule that would have been implemented, had the rule been adopted over history.

Figure 1 provides a birds-eye view of the federal funds rate and the Taylor rule from 1966 to 1998 using "current" data. ${ }^{5}$ To fix notation, for any variable $x$, let $x_{i \mid j}$ be the value

\footnotetext{
${ }^{5}$ By "current" or "final" data I mean data available when the snapshot of data used for this analysis was taken. Of course, "final" data corresponding to later snapshots will differ. Here, I rely on data as available
} 
of the variable for quarter $i$ as provided by the relevant agency in quarter $j$. (I use the subscript $T$ to denote the current data vintage.) Let $d$ be the log of the output deflator, $q$ the $\log$ of real output and $q^{*}$ the $\log$ of potential output. For the rule shown in the figure, I employ the chain-weighted GDP deflator as published by the U.S. Commerce Department and construct the measure of inflation used for quarter $t$ as $\pi_{t-1 \mid T}=d_{t-1 \mid T}-d_{t-5 \mid T}$. To construct the output gap, I use the Commerce Department estimates of real GDP and the potential output estimates published by the Congressional Budget Office (CBO), both measured in chain-weighted 1992 dollars. ${ }^{6}$ The output gap measure for quarter $t$ is then $y_{t-1 \mid T}=q_{t-1 \mid T}-q_{t-1 \mid T}^{*}$

Comparison of the federal funds rate and the Taylor rule shown in figure 1 provides the basis for the favorable historical assessment of the rule when examined with the benefit of hindsight. Since the late 1980s the rule broadly follows the contours of actual policy. In the earlier years policy appears to have been systematically easier and more volatile than the rule in the 1970s and considerably tighter subsequently. The systematic difference of actual policy from the rule in the late 1960s and 1970s, in particular, is taken as evidence that had the rule been followed the Great Inflation could have been averted. This finding, in turn, has been interpreted as indicating that the rule may be robust to the problems that led to policy errors during the 1970s.

\section{A Closer Look at the 1970s}

To examine the Taylor rule in a more realistic way for the 1970s, I reconstructed the prescriptions of the Taylor rule using data as available in each quarter from 1968:4 to 1979:4. That is, I computed the rule replacing the current inflation and gap measures, $\pi_{t-1 \mid T}$ and $y_{t-1 \mid T}$ in the rule with their equivalent measures available to the public in quarter $t, \pi_{t-1 \mid t}$ and $y_{t-1 \mid t}$. The continuing conceptual and definitional changes of the underlying data, of course, requires greater specificity about the exact data that should be used for this on October 1999, when I originally put together the dataset for this study.

${ }^{6}$ These are the same series as employed by the Federal Reserve Bank of St Louis for the Taylor rule published in the Monetary Trends. Taylor (1999b) relied on a Hodrick-Prescott trend definition for potential output. This is essentially similar to the CBO series over the historical period relevant for this analysis. 
purpose. The guideline I follow is to use in every quarter published data that would most closely correspond to the key concepts required for the Taylor rule, that is, the concepts "real output," "output deflator," and "output gap" or "potential output" as were available and used at the time.

Some details are in order. The headline concept for aggregate output during the 1970s was GNP instead of the current choice of GDP. Further, instead of the current chainweighted concept for the output deflator, and associated estimates of real output, a fixedweight constant-dollar concept was employed at that time. In my sample, the deflator and associated real output were stated in 1958 constant dollars until 1975:4 and in 1972 constant dollars from 1976:1 on. Data for nominal and real output from which one could construct the output deflator inflation were published with a one-quarter lag by the Commerce Department, for instance, in the monthly publication Survey of Current Business. I use these data to construct the inflation measure $\pi_{t-1 \mid t}=d_{t-1 \mid t}-d_{t-5 \mid t}$. During this period, in addition to estimates of actual GNP, an official estimate of potential GNP was published by the government. This series was constructed and updated by the Council of Economic Advisers. Starting with 1962, these estimates were regularly provided in the Annual Report of the Council of Economic Advisers which was published with the Economic Report of the President. (The publication of this official series continued until 1981.) From 1968:4 to 1976:4, in particular, the Commerce Department employed these data to publish updated estimates of actual GNP, potential GNP and the associated output gap in the monthly publication Business Conditions Digest. (This publication has been discontinued.) I use the data published there for the latest output gap data available in each quarter $t$, defined as $y_{t-1 \mid t}=q_{t-1 \mid t}-q_{t-1 \mid t}^{*}$. From 1977:1 to 1979:4 I did not find monthly or quarterly Commerce Department publications with estimates of potential output. As a result, for these three years, I relied on the data presented in the 1977, 1978 and 1979 Economic Report of the President for estimates of potential output. I constructed first estimates of the output gap by combining these estimates with the first GNP estimates published by the Commerce Department in the Survey of Current Business. ${ }^{7}$

\footnotetext{
${ }^{7}$ Usage of the official series for potential output was quite common during the 1970s. Plots and discussion
} 
Figure 2 compares the resulting real-time Taylor rule with its current rendition, reproduced from figure 1 , and the actual setting of the federal funds rate. As can be seen from this figure, prescriptions implied by the Taylor rule at the time policy decisions were made appear surprisingly close to actual policy throughout the 1970s. The rule captures quite accurately the two major policy easing episodes associated with the recessions of 1970 and 1974 and the subsequent policy tightenings. And in stark contrast to the current rendition, it does not suggest that policy was consistently more expansionary than the Taylor rule. These findings cast considerable doubt on the hypothesis that the macroeconomic outcomes of the 1970s would have been dramatically different if policy were set according to the rule, using information available to the public at the time. ${ }^{8}$

\section{Accounting for the Differences}

The size of the discrepancy between the current and real-time renditions of the Taylor rule warrants further explanation. Since the difference can be attributed to discrepancies between the current and real-time measures of the two inputs to the rule, inflation and the output gap, a detailed accounting of this difference is immediate.

Figure 3 shows the underlying data for these two variables. The upper panel compares the two inflation measures, $\pi_{t-1 \mid t}$ and $\pi_{t-1 \mid T}$ and shows that these measures differ substantially at times. During the two crucial years preceding the 1974 acceleration of inflation, for instance, the real-time measures consistently understated inflation by over one percentage point, as compared to current estimates. In terms of the Taylor rule which prescribes a change of one and a half percentage point in the federal funds rate for every percentage point change in inflation, this suggests that the rule prescription in real-time would have been over 150 basis points lower than the current data suggest for those two years.

Most of the systematic difference between the current and real-time renditions of the Taylor tule, however, is due to the difference between the real-time and current estimates

of the series can even be found in several textbooks published at the time, including Samuelson (1976), Branson and Litvack (1976), Dornbusch and Fischer (1978) and Meyer (1980).

${ }^{8} \mathrm{~A}$ quantitative assessment of how large the difference in such outcomes might have been had the rule been followed could be performed with model-based counterfactual simulations. (See e.g. Orphanides, 2000.) However such comparisons would be dependent on the specification of the model. 
of the output gap, $y_{t-1 \mid t}$ and $y_{t-1 \mid T}$, shown in the lower panel of figure 3. From the current perspective, the real-time output gap series for this period appears to have been systematically biased. This bias, which at the start of the sample in 1969 was about two percentage points, increased considerably during the early 1970s - exceeding ten percentage points by 1975 - before improving towards the end of the 1970s. In terms of the Taylor rule which assigns a weight of one-half on the output gap, this suggests that the rule prescription during the 1970s would have been anywhere from 100 basis points to over 500 basis points lower than what current data would suggest.

Mismeasurement of the output gap can be attributed to either mismeasurement of the level of actual output or the level of potential output. Attempting an exact decomposition of these errors into these two sources can be quite involved. Figure 4 provides some indicative estimates for the contribution of actual output mismeasurement to these errors. The upper panel compares the quarterly growth rates of real output with current data, $\left(q_{t-1 \mid T}-q_{t-2 \mid T}\right)$, to their real-time counterparts, $\left(q_{t-1 \mid t}-q_{t-2 \mid t}\right)$. (These estimates are in percent quarterly rates.) As is evident, differences in these growth rates can at times exceed one percent. On their own, these one-quarter errors do not appear that unusual. However, this obscures a potentially important problem associated with the measurement of the level of a variable such as output. An accumulation of even small errors in the growth rates could, at times, generate an error of several percentage points in the measurement of the level. Compare, for instance, the cumulative output growth for the previous three years as seen in 1975:1, $\left(q_{1974: 4 \mid 1975: 1}-q_{1971: 4 \mid 1975: 1}\right)$, with the growth over the same period as seen with current data, $\left(q_{1974: 4 \mid T}-q_{1971: 4 \mid T}\right)$. Using the current data suggests that relative to the 1971:4 baseline, output in 1974:4 was three percentage points higher than using the real-time data. This disparity provides a measure of the mismeasurement of the level of output but only a rough measure because it depends on how reliable the comparison of the baseline quarter (here 1971:4) would be. The lower panel of figure 4 repeats these calculations for every quarter in the sample. The resulting cumulative discrepancy in the level of real output is shown for two horizons, two and three years, to show how the results change with alternative 
baselines. That is, in each quarter, $t$, the plot shows:

$$
\left(q_{t-1 \mid T}-q_{t-1-k \mid T}\right)-\left(q_{t-1 \mid t}-q_{t-1-k \mid t}\right)
$$

for $k=8$ (two-year horizon) and $k=12$ (three-year horizon). These cumulative errors suggest that the measurement of real output was too pessimistic following both the 1970 and 1974 recessions and could account for a significant portion of the mismeasurement of the output gap. The worst errors, in 1975, coincide with the worst errors in the output gap measures shown in figure 3 and can account for as much as five percentage points of the output gap mismeasurement that year.

This illustrates that mismeasurement of the level of actual output was a significant contributing factor to the mismeasurement of economic activity in the 1970s. But a substantial and highly persistent discrepancy between the real-time and current estimates of the output gap still remains. This must be attributed to estimates of potential output that proved, in retrospect, to have been too optimistic. Indeed, a major problem with the real-time output gap estimates in the early 1970s, is that they were based on estimates of potential output which were shaped by the extraordinary performance of the economy during the 1950s and 1960s. In this sample, potential output was projected to grow at an annual rate of 4 percent until the end of 1969, an estimate that was raised to 4.3 percent in 1970 . Based on current data and the experience of the past thirty years, this may appear very optimistic. The average growth of real output from 1970 to 1998 was 2.8 percent per year. However, growth from 1950 to 1969 averaged 4.2 percent per year and at the time it was believed that potential output growth had accelerated somewhat in the late 1960s. The deterioration in economic growth we now identify with the "productivity slowdown," which had already started in the late 1960s, was not recognized until considerably later. Potential output growth estimates were revised downward in the 1970s, to 4 percent in 1974, 3.75 percent in 1976, 3.5 percent in 1977 and 3 percent in 1979. But for the whole decade, these revisions lagged behind the reduction in potential output growth implicit in current estimates as constructed with the benefit of hindsight.

Another factor contributing to the mismeasurement of the output gap during the early 
1970s, was an implicit assumption at the beginning of the decade that the natural rate of unemployment was four percent. But following the experience of unexpectedly high unemployment and inflation, especially during 1974 and 1975, this assumption was also brought into question and revised upwards, to 4.9 in 1977 and 5.1 in 1979. By contrast, the current $\mathrm{CBO}$ estimate for that time is about six percent or higher. ${ }^{9}$

Okun's law (Okun, 1962) provides a rule of thumb for the extent of mismeasurement of the output gap associated with such incorrect estimates of the natural rate. According to this law, as was applied at the time, the output gap was believed to be roughly equal to three times the unemployment gap. (More recently this same relationship is being applied with a lower coefficient, e.g. 2-2.5.) Thus, if the natural rate assumption in the early 1970s was 2 percentage points too optimistic, Okun's law would suggest that potential output estimates could be about 6 percentage points too optimistic as well. ${ }^{10}$

\section{The Evolution of Beliefs, Policy, and Inflation}

In retrospect, it is clear that mistaken beliefs regarding potential output growth and the natural rate of unemployment at the start of the 1970s, coupled with a slow pace of adjustment of these beliefs in the face of a continuing deterioration in the nation's productive capacity prospects, resulted in estimates of the level of potential output and the output gap that were consistently too optimistic during the 1970s. A pertinent question is whether policymakers did or should have considered the official estimates of the output gap overly optimistic in real time. Based on information available at the time, in the early 1970s it was not evident that the official estimates should have been controversial. ${ }^{11}$ As Peter Clark

\footnotetext{
${ }^{9}$ With the 1982 recession, the uncertainty of these estimates became even higher, and point estimates also rose, as reflected in Tobin (1983): "Unfortunately no one knows what the NAIRU is. Current estimates for the United States vary from 8 percent to 5 percent" (p. 512).

${ }^{10}$ Although potential output was not constructed using Okun's law, it was influenced by the baseline assumption that the economy was at potential in mid 1955 with unemployment near four percent and stable prices. Consequently, using deviations of unemployment from four percent and Okun's law was considered a useful rough guide for the output gap.

${ }^{11}$ Robert Solow (1982) provides an enlightening analysis of what went wrong with the Council's original estimates of potential output. His account attributes most of the error to the unexpected unfavorable shift in trend productivity that started in the 1960s. Evidence documenting the unreliability of end-of-sample business cycle estimates, e.g. Christiano and Fitzgerald (1999) and Orphanides and van Norden (2002) suggests that mistakes of this nature are largely unavoidable.
} 
observed in $1979:^{12}$

"Research on potential GNP from 1964 to 1974 produced a number of different views on the best estimation technique, but very little disagreement about the estimates themselves. All the results were similar to the CEA estimates or even somewhat higher." (p. 141.)

Although the nexus of inflation, output and unemployment from 1970 to 1972 was considered somewhat puzzling, it was the surprising acceleration of inflation in 1973-while output was still well below potential and unemployment substantially higher than four percentthat prompted a reexamination of the earlier estimates. ${ }^{13}$ In January 1974 the Council of Economic Advisers acknowledged increased uncertainty regarding estimates of potential output and revised downward earlier estimates of both the level and growth rate of potential output. The energy crisis and associated recession which spanned 1974 and continued into early 1975, made it extremely difficult to separate any further changes in the underlying trend of potential output from cyclical developments during these two years. The estimate of potential output growth was then revised downward in early 1976 and a major effort to revamp the historical estimates of potential output was initiated that year which resulted in the major revision evident in the data in January 1977. The 1977 revision reduced the estimate of potential output for 1976 by 4 percentage points and brought the spectacular gap for $1975 \mathrm{Q} 2$ (which was first reported to be about 15 percent) down to 10 percent. $^{14}$ In retrospect, even these revised figures from the late 1970s appear overly optimistic when compared to current estimates. However, at the time this was not at all clear and one could even reasonably argue that the Council revisions were too pessimistic. ${ }^{15}$ Estimates used at the time by professional forecasting groups such as Data Resources Incorporated and

\footnotetext{
${ }^{12}$ Clark's views are particularly useful as his work during 1976 resulted in the major improvement in the official estimates of potential output which was published in 1977.

${ }^{13}$ As shown in Figure 3, this inflation acceleration appeared much sharper in real time due to the pattern of mismeasurement in inflation in these years. In retrospect, of course, this is not at all puzzling, considering the severe overheating of the economy in 1973 depicted in the current data in the bottom panel of the figure.

${ }^{14}$ By 1979, the gap for 1975Q2 was further revised downwards, closer to 8 percent, and kept shrinking with subsequent revisions.

${ }^{15}$ See e.g. Perry (1977) and the discussion following his article for a range of views and estimates spanning the Council's revisions.
} 
Wharton Econometrics were not dramatically different either. ${ }^{16}$

Whether any of these revisions should have been carried out earlier or should have been anticipated by policymakers remains a difficult question. It is indeed possible that policymakers anticipated some of these revisions before their official publication. For a revision as large as the one published in 1977, in particular, some of the change may have been anticipated prior to the official release of the new estimates. Returning to figure 2, it is interesting to note that based on the published real-time data, the setting of the federal funds rate prior to this revision, during 1976, was consistently about two hundred basis points higher than the Taylor rule. This policy is equivalent to a setting of the Taylor rule with an output gap estimate that is four percentage points lower than the official estimates published in 1976 - exactly the revision for 1976 reflected in the 1977 estimates of potential output. Thus, during 1976, actual policy was consistent with the Taylor rule adjusting for the large subsequent revision in potential output that was published in January 1977.

To confirm whether misperceptions regarding the output gap actually influenced the monetary policy process, it is useful to examine direct evidence from the deliberations of the FOMC. An enlightening example appears in the FOMC Memorandum of Discussion for the contentious August 18, 1970, meeting. This was in the context of the series of easings that had started in February to counteract the recession underway. The August meeting was important in that by then real activity had stopped deteriorating and the staff was forecasting a modest expansion. ${ }^{17}$ The record shows that close to the end of the meeting the committee was evenly split, with six members (including the Chairman) voting in favor of a directive calling for additional easing and six members voting in favor of an alternative that would have essentially maintained an unchanged policy stance. Members opposing further easing pointed to the need to concentrate on reducing inflation which had fallen in the second quarter but was still over four percent. However, other members were

\footnotetext{
${ }^{16}$ For example, in the introduction to his book on "The Great Recession," which was completed in 1976, DRI's Otto Eckstein observed that "[b]y the trough of the recession in the spring of 1975, real GNP had fallen $14.5 \%$ below the full employment path" (p. 1)

${ }^{17}$ Data for the second quarter which had become available in the inter-meeting period indicated real GNP had grown by 0.5 percent as compared to the 5.4 percent drop in the first quarter. Figure 5 presents historical data and forecasts of inflation and output (as well as the official estimate of potential) as available at the meeting.
} 
concerned that the level of economic activity was not improving fast enough and at the end of the meeting an easing was adopted. Referring to the staff forecasts of GNP, a governor is reported to have explained the need for this easing by noting that: "If those projections were realized, however, the gap between actual and potential real GNP would be between 5.5 and 6 per cent by the second quarter of 1971. In his judgment, that was not satisfactory as a goal of policy." (p. 45.) Indeed, these projections proved quite accurate-based on the official estimates of potential output available at the time. But in retrospect, these projected gaps appear spectacularly off the mark. ${ }^{18}$

The record for the meeting also indicates that committee members were in agreement that policy should continue to aim towards reducing inflation. Given the perceived slack in economic activity, however, easing policy was not considered inconsistent with this objective by the majority. As stated in the policy directive (adopted with three dissenting votes), “... it is the policy of the Federal Open Market Committee to foster financial conditions conducive to orderly reduction in the rate of inflation, while encouraging the resumption of sustainable economic growth." (p. 66). Indeed, from the perspective of the Taylor rule, the policy adopted during that meeting was consistent with the long-run inflation target of two percent that is implicit in the rule - conditioning on the official output gap estimates available at the time.

Incorrect assessment of the economy's potential influenced the staff's advice to the Committee as well. During 1975, when these misperceptions appeared to be at their worst, the staff suggested that a policy of further easing could be pursued with little concern about inflation, despite the high degree of monetary accommodation that was already in place. At the May 1975 meeting, for example, the staff argued that “... there is such a large amount of slack in the economy now that real growth would have to exceed our projection by a wide margin, and for an extended period, before excess aggregate demand once again emerged as a significant problem." (FOMC Memorandum of Discussion, May 1975, p. 26). And

\footnotetext{
${ }^{18}$ The reference to projected output gaps also indicates awareness of the need to be "forward-looking" in setting policy. Indeed, the policy discussions suggest that throughout this period, decisions were greatly influenced by the projected outlook for inflation and economic activity. Orphanides (2002, 2003) confirms that estimated policy rules based on Federal Reserve Board staff forecasts can be used to characterize these policy decisions.
} 
further, "[s]imulations using the econometric model suggested that a considerably faster rate of expansion could be stimulated without having a significant effect on the rate of increase in prices - that a considerably more rapid rate of increase in real GNP would still be consistent with a further winding down of inflationary pressures" (p. 27). In the event, the FOMC did not pursue a policy of greater accommodation, and yet inflation outcomes for the rest of 1975 and for 1976 were worse than anticipated by the staff. The incorrect assessments of the economy's potential at the time, of course, influenced the forecasting process, and inflation forecasts also proved too optimistic.

To be sure, this evidence does not imply that FOMC policy during the 1970s literally "followed" the Taylor rule. What it does indicate is that policy was influenced by the same considerations as are embedded in the Taylor rule, namely deviations of inflation from the Federal Reserve's low inflation objective, and deviations of economic activity from perceptions of the economy's sustainable economic growth path. Furthermore, it illustrates that because of the emphasis the rule places on the concept of the "gap," the rule itself becomes susceptible to the exact same problems apparent in the activist discretionary stabilization strategy pursued during the 1970s.

The fact that actual policy during the 1970s does not greatly differ from the Taylor rule as could be implemented in real time also suggests that examining the implications of following the rule in the presence of misperceptions regarding potential output - or the related concept of the natural rate of unemployment - could potentially be useful for understanding the acceleration of inflation during the early 1970s. A rule of thumb on how much of the inflation pickup could be attributed to mismeasurement of the output gap with the Taylor rule can be derived by determining the steady state of inflation compatible with a constant level of mismeasurement in the rule. From equation (1), in steady state $\left(\pi-\pi^{*}\right)+y=0$, so any perceived persistent output gap would exactly balance a persistent deviation of inflation from its target. For example, an inflation rate of eight percent, instead of the two percent target in the rule, could be consistent with a persistent six percentage point error in the output gap or, using Okun's law as described earlier, a two percentage point misperception 
of the natural rate of unemployment. To the extent the Taylor rule is believed to provide a reasonable guide to monetary policy, an inflationary outcome such as this should not be entirely unexpected as errors of this nature simply reflect the ignorance associated with real-time assessments of the economy's potential.

Key policy figures later admitted that a mistake of this nature - if not exact magnitude had indeed been committed. Shortly after leaving the Federal Reserve, Arthur Burns (1979) pointed to the delay in recognizing the increase in the natural rate and the productivity slowdown in the late 1960s and 1970s as two major factors for the inflationary outcomes of the period. Herbert Stein, who served as member and later chairman of the Council of Economic Advisers during the Nixon administration, identified the belief that the natural rate was four percent and its implications for inflation "the most serious error of the Nixon CEA" (p. 19). As he explained: "fascinated by the idea of "the natural rate of unemployment,' which we thought to be 4 percent, we thought it necessary only to let the unemployment rate rise slightly above that to hold down inflation.” (p. 19-20.) ${ }^{19}$

\section{Conclusion}

Activist stabilization policies require prompt and accurate assessments of the level of economic activity in relation to a concept of the economy's potential. As a practical matter, considerable uncertainty frequently obscures the current state of the economy and renders measures such as the "output gap" and the "unemployment gap" highly unreliable in real time. Although policies that rely on these measures may appear promising in the absence of these difficulties, such policies can easily prove counterproductive in practice. This paper uses the inflationary experience of the 1970s as a laboratory to show that recently proposed monetary policy rules that react to such "gaps" are as susceptible to these difficulties as earlier discretionary policies guided by similarly activist objectives.

To be sure, this does not diminish the appeal or the importance of rule-based or rule-

\footnotetext{
${ }^{19}$ To their credit and unlike many other economists at the time, Burns and Stein had already subscribed to Friedman's (1968) natural rate view by the end of the 1960s. As a result, they avoided the additional problems associated with the perception of a long-run tradeoff between inflation and unemployment. Sargent (1999) demonstrates the inflationary consequences of policy driven by such perceptions.
} 
like policy. But it does point to the desirability of examining more robust alternatives to policies emphasizing "gaps" for policy design. Also, the unfavorable outcomes of the pursuit of gap-based policies cannot be necessarily seen as evidence favoring the monetary growth targeting approach proposed by monetarists at the other end of the debate. The difficulties experienced in the early 1980s with the various variants of M1 as well as the questions about M2 in the early 1990s suggest that, although they can be very useful at times, monetary growth targeting strategies are far from an ideal solution, and that they also would require modifications and discretion in practice.

The middle ground, perhaps, could be in the direction of strategies that concentrate neither on gaps, nor on money growth targeting, but on a common objective related to both, the stability of growth in the economy, and nominal income. Tobin emphasized this middle ground during the $1980 \mathrm{~s}$, when difficulties at both ends of the activist-monetarist debate were better understood.

"I will state my view very bluntly. The long-run targets of the Federal Reserve should be expressed as a path of nominal GNP ...

These targets should take precedence over any short-run instrument targets for monetary aggregates or interest rates. It should be made clear that both the Fed's instruments and those intermediate targets will be varied so as to keep nominal GNP on track - not of course month to month or quarter to quarter but on average year to year." (Tobin 1981, 1987, p. 373)

"For two years ahead, the intermediate target should be nominal GNP growth ... This would indicate how the policymakers would allow price and productivity shocks to affect output and employment, while allowing complete freedom to offset velocity-of-money surprises with money supplies. Indeed, the Fed might advertise this target as a velocity-adjusted monetary aggregate ..." (Tobin 1983, $516)$

Other economists during the 1980s, including some who had earlier been more optimistic about the usefulness of "output gaps" and "unemployment gaps" as guides, also suggested moving to this middle ground. For example, Arthur Okun agreed that "[policymakers] do not serve the nation well if they concentrate on output and employment targets - whether the objective is set forth as achieving full employment, the natural unemployment rate, or potential GNP" (1981, p. 354). Rather, he concluded, an efficient macroeconomic strategy 
could be designed based on "adoption of the objective of growth in nominal GNP" (p. 357). From the other end of the debate, in a careful examination of the usefulness and limitations of money growth targeting strategies, McCallum (1985) also concluded that "an intermediate target strategy could more fruitfully be based on the path of nominal GNP than of the money stock" (p. 591). Concentrating on nominal income for guiding policy appeared to evolve into a strategy with many proponents seeking to balance the desire for reasonable economic performance against the temptation of excessive activism. Commenting on McCallum (1985) Tobin characteristically remarked: "Let us rejoice that views are converging" (1985, p. 607).

With our limited knowledge of the workings of the economy, we can never be certain that we have successfully identified the best approach for stabilization policies. We can only hope that by seeking guidance from the past, especially understanding the underlying problems that likely led to earlier mistakes, we can avoid repeating the most glaring of such mistakes going forward. The recently proposed policy rules that emphasize a gap-based approach to monetary policy seem to capture the essence of the stabilization approach that was in place during the 1960s and 1970s. With correct readings of the state of the economy such policies may be successful. However, the 1970s provide a striking example when such strategies were much less successful. To the extent the macroeconomic outcomes of the 1970s are not considered particularly favorable, the usefulness of such monetary policy rules as guides for monetary policy decisions ought to be carefully examined. 


\section{References}

Blinder, Alan (1979), Economic Policy and the Great Stagflation, San Francisco: Academic Press.

Branson, William H. and James M. Litvack (1976), Macroeconomics, New York: Harper \& Row.

Brunner, Karl (1985), "Monetary Policy and Monetary Order," in Monetary Policy and Monetary Regimes, Center for Research in Government Policy and Business, Number CS-17, Rochester, N.Y.: Graduate School of Management, University of Rochester.

Bryant, Ralph C., Peter Hooper and Catherine Mann eds., (1993), Evaluating Policy Regimes: New Research in Empirical Macroeconomics, Washington DC: Brookings.

Burns, Arthur (1979), The Anguish of Central Banking, The 1979 Per Jacobsson Lecture, Belgrade, Yugoslavia, September 30.

Christiano, Lawrence J., and Terry J. Fitzgerald (1999), "The Band Pass Filter," NBER Working Paper, No. 7257, July.

Clarida, Richard, Jordi Gali, and Mark Gertler (1999), "The Science of Monetary Policy: A New Keynesian Perspective" Journal of Economic Literature, 37(4), 1661-1707, December.

Clark, Peter K. (1979), "Potential GNP in the United States, 1948-80," Review of Income and Wealth, 25(2), 141-165, June.

De Long, Bradford (1997), “America's Only Peacetime Inflation: The 1970's," in Romer and Romer, eds, (1997).

Dornbusch, Rudiger and Stanley Fischer (1978), Macroeconomics, New York: McGraw-Hill.

Eckstein, Otto (1978), The Great Recession With a Postcript on Stagflation, Amsterdam: North-Holland.

Federal Open Market Committee (Various Years), Memorandum of Discussion, Federal Reserve Board, Washington, D.C.

Fischer, Stanley (1990), "Rules Versus Discretion in Monetary Policy," in B. Friedman and F. Hahn (eds.), Handbook of Monetary Economics, North-Holland, Amsterdam.

Friedman, Milton (1947), "Lerner on the Economics of Control," in Friedman (1953).

Friedman, Milton (1953), Essays in Positive Economics, Chicago: University of Chicago.

Friedman, Milton (1968), "The Role of Monetary Policy," American Economic Review, 58(1) 1-17, March.

Heller, Walter, Kermit Gordon, and James Tobin (1961), "The American Economy in 1961: Problems and Policies," in January 1961 Economic Report of the President and the Economic Situation and Outlook, Hearings before the Joint Economic Committee, Congress of the United States, U.S. Government Printing Office, Washington, D.C. 
Hetzel, Robert (1998), "Arthur Burns and Inflation," Federal Reserve Bank of Richmond Economic Quarterly, 84(1), 21-44, Winter.

Levin Andrew, Volker Wieland and John Williams (1999), "Robustness of Simple Policy Rules Under Model Uncertainty," in Taylor (1999a).

Mayer, Thomas (1999), Monetary policy and the Great Inflation in the United States: The Federal Reserve and the Failure of Macroeconomic Policy, 1965-1979, Edward Elgar, Cheltenham.

McCallum, Bennett T. (1985), "On Consequences and Criticisms of Monetary Targeting," Journal of Money, Credit and Banking, 17(4), Part 2, November, 570-597.

McCallum, Bennett T. (1994), "Specification of Policy Rules and Performance Measures in Multicountry Simulation Studies," Journal of International Money and Finance, 13(3), 259-275, June.

McCallum, Bennett T. (1999), "Issues in the Design of Monetary Policy Rules," in Taylor and Woodford (1999).

McCallum, Bennett T. and Edward Nelson (1999), "Performance of Operational Policy Rules in An Estimated Semi-Classical Structural Model," in Taylor (1999a).

Meltzer, Allan H. (1987), "Limits of Short-Run Stabilization Policy," Economic Inquiry, $25,1-14$.

Meyer, Laurence (1980), Macroeconomics: A Model Building Approach, Cincinnati: SouthWestern.

Okun, Arthur (1962), "Potential Output: Its Measurement and Significance," in American Statistical Association 1962 Proceedings of the Business and Economic Section, Washington, D.C.: American Statistical Association.

Okun, Arthur (1981), Prices and Quantities: A Macroeconomic Analysis, Brookings, Washington D.C.

Orphanides, Athanasios (1998), "Monetary Policy Evaluation With Noisy Information," Finance and Economics Discussion Series, 1998-50, Federal Reserve Board, October.

Orphanides, Athanasios (2000), "The Quest for Prosperity Without Inflation," ECB Working Paper No. 15, March.

Orphanides, Athanasios (2001), "Monetary Policy Rules Based on Real-Time Data," American Economic Review, 91(4), 964-986, September.

Orphanides, Athanasios (2002), "Monetary Policy Rules and the Great Inflation," American Economic Review, 92(2), 115-120, May.

Orphanides, Athanasios (2003), "Monetary Policy Rules, Macroeconomic Stability and Inflation: A View from the Trenches," Journal of Money, Credit and Banking, forthcoming. 
Orphanides, Athanasios, and Simon van Norden (2002), "The Unreliability of Output Gap Estimates in Real Time," Review of Economics and Statistics, forthcoming.

Perry, George (1977), "Potential Output and Productivity," Brookings Papers on Economic Activity, 1, 11-47.

Romer, Christina and David Romer eds. (1997), Reducing Inflation: Motivation and Strategy, Chicago: University of Chicago.

Samuelson, Paul A. (1976), Economics, 10th ed. New York: McGraw-Hill.

Sargent, Thomas (1999), The Conquest of American Inflation, Princeton: Princeton University Press.

Solow, Robert M. (1982), "Where Have All the Flowers Gone? Economic Growth in the 1960s," in Joseph A Pechman and N. J. Simler eds., Economics in the Public Service: Essays in Honor of Walter W. Heller New York: Norton.

Stein, Herbert (1996), "A Successful Accident: Recollections and Speculations about the CEA," 10(3), 3-21, Summer.

Taylor, John B. (1993), "Discretion versus Policy Rules in Practice," Carnegie-Rochester Conference Series on Public Policy, 39, December, 195-214.

Taylor, John B. (1998), "The Robustness and Efficiency of Monetary Policy Rules as Guidelines for Interest Rate Setting by the European Central Bank," May.

Taylor, John B., ed., (1999a), Monetary Policy Rules, Chicago: University of Chicago.

Taylor, John B. (1999b), "An Historical Analysis of Monetary Policy Rules," in Taylor (1999a).

Taylor, John B. and Michael Woodford, eds. (1999), Handbook of Macroeconomics, Amsterdam: Elsevier.

Tobin, James (1966), National Economic Policy, New Haven: Yale University Press.

Tobin, James (1972), New Economics One Decade Older, Princeton: Princeton University Press.

Tobin, James (1981) "Strategy for Disinflation," The Conference Board Colloquium on Alternatives for Economic Policy Proceedings, June, reprinted in Tobin(1987)

Tobin, James (1983), "Monetary Policy: Rules, Targets, and Shocks," Journal of Money, Credit and Banking, 15(4), 506-518, November.

Tobin, James (1985), "Comment on On Consequences and Criticisms of Monetary Targeting, or Monetary Targeting: Dead at Last," Journal of Money, Credit and Banking, 17(4), Part 2, November, 605-609.

Tobin, James (1987), Policies for Prosperity: Essays in a Keynesian Mode, MIT Press, Cambridge, MA. 
Tobin, James (1998), "Monetary Policy: Recent Theory and Practice," Cowles Foundation Discussion Paper 1187.

Wessel, David (2000), "Could One Little Rule Explain All of Economics?" Wall Street Journal, February 7. 
Figure 1

Federal Funds Rate and Taylor Rule with Current Data

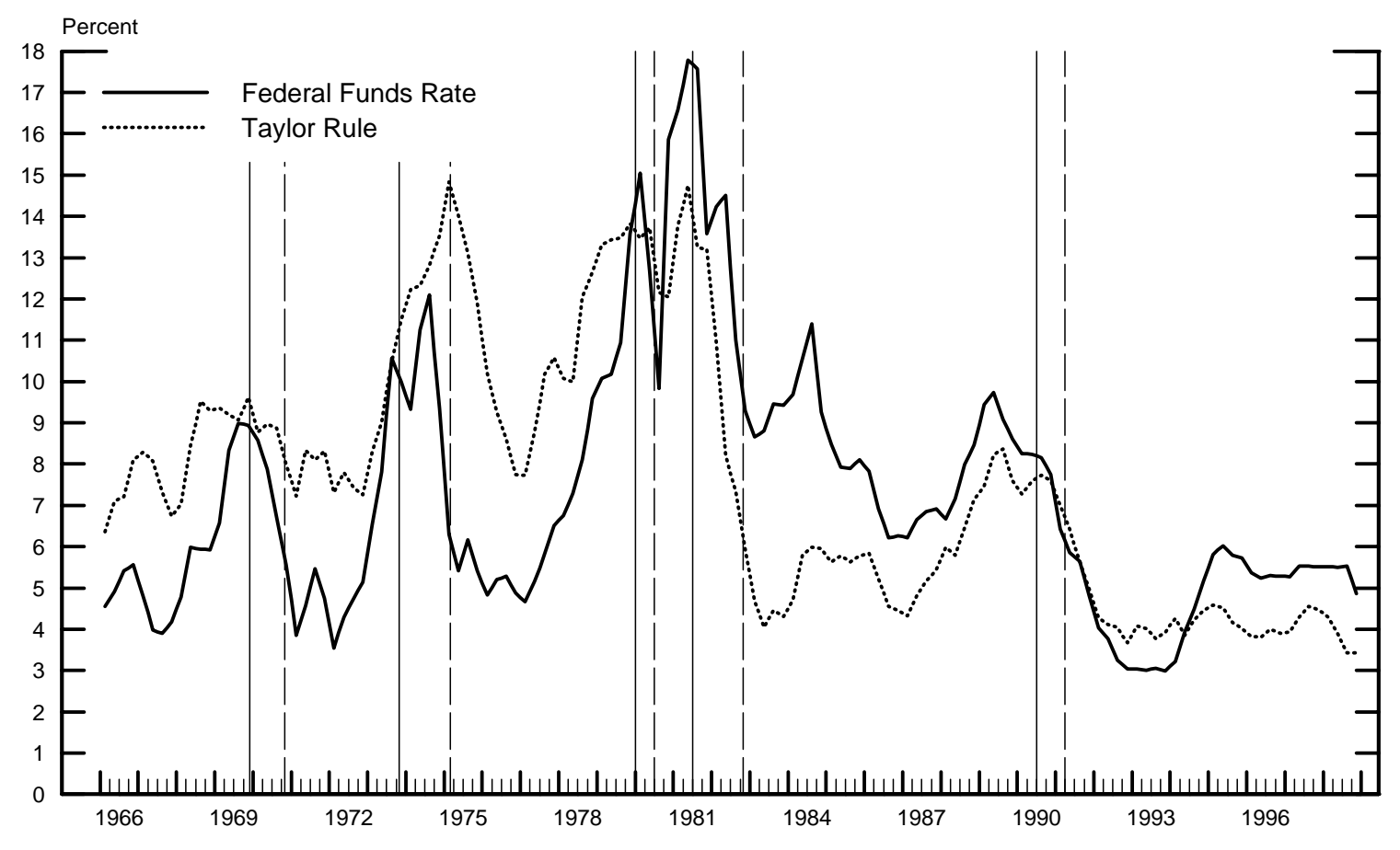

Notes: The solid and dashed vertical lines represent NBER business cycle peaks and troughs, respectively. 
Figure 2

\section{The Taylor Rule with Real-Time and Current Data}

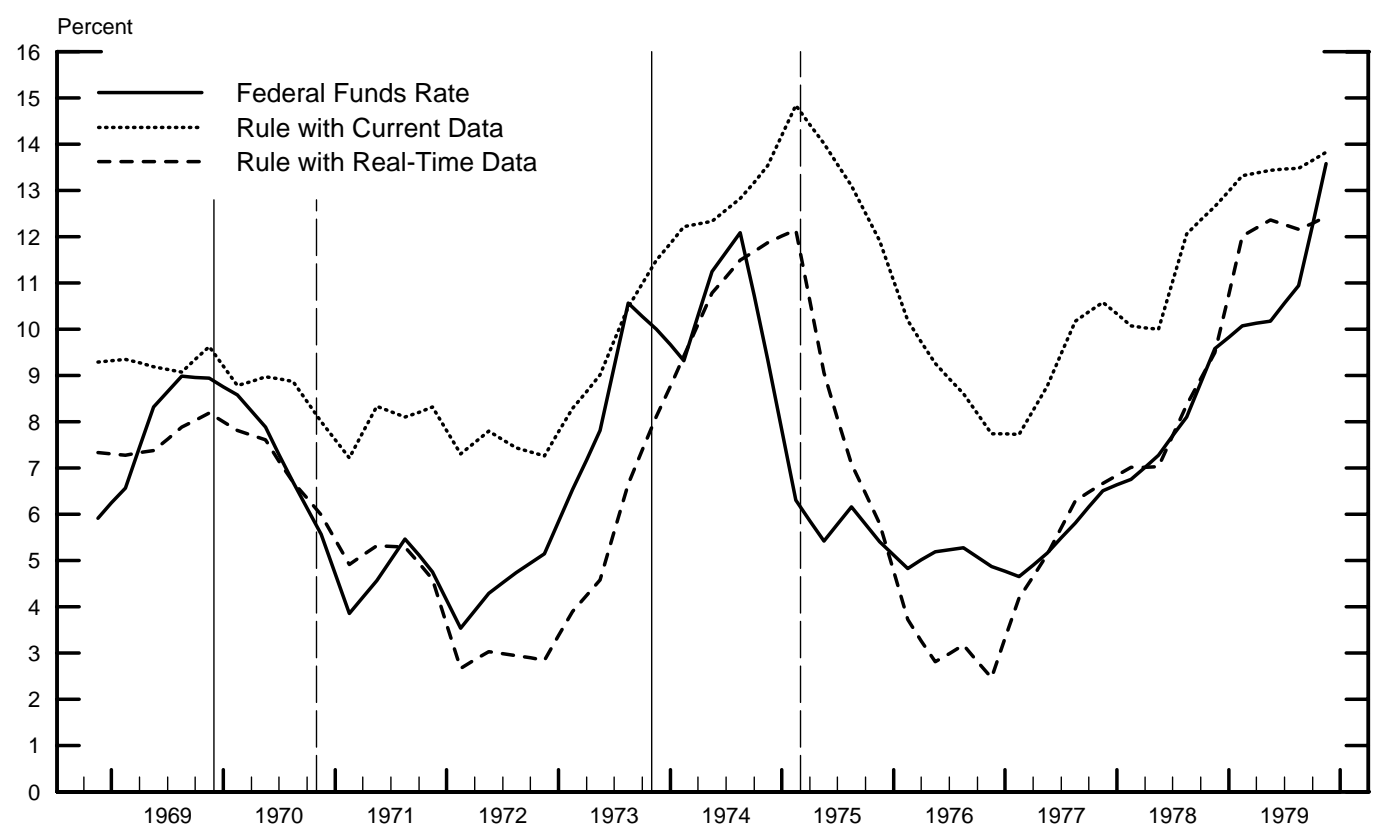

Notes: The real-time rule is based on information as available in quarter $t$ based on first published data for quarter $t-1$. The current rule is based on current estimates of the historical data for the corresponding quarter. See also notes to figure 1 . 
Figure 3

\section{Underlying Current and Real-Time Data}

\section{Inflation}
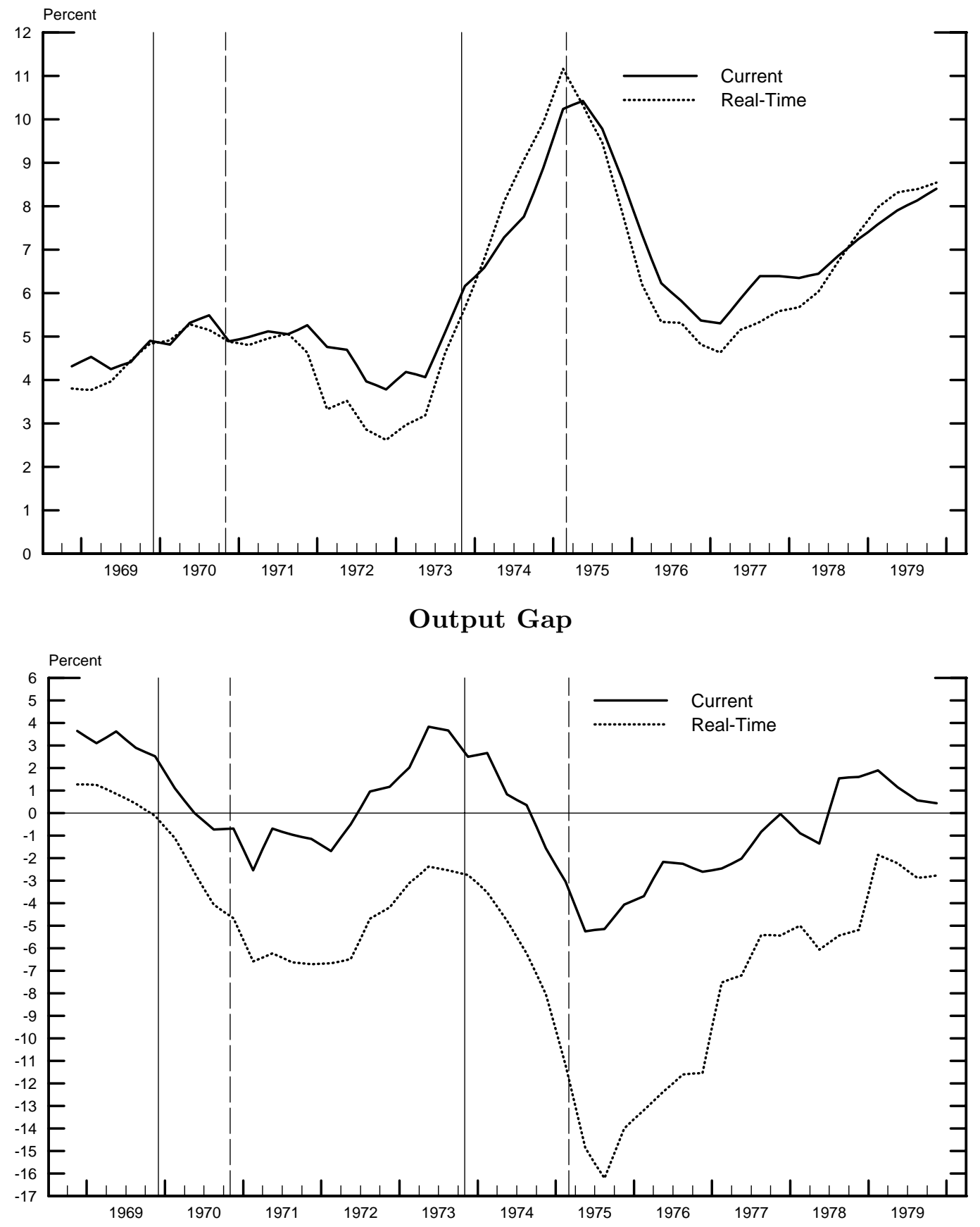

Notes: Inflation is the log change in the output deflator over four quarters ending with $t-1$, in percent. The output gap is the log difference between real output and potential output, in quarter $t-1$, in percent. See also notes to figures 1 and 2 . 


\section{Real Output Mismeasurement}

\section{Real Output Growth}

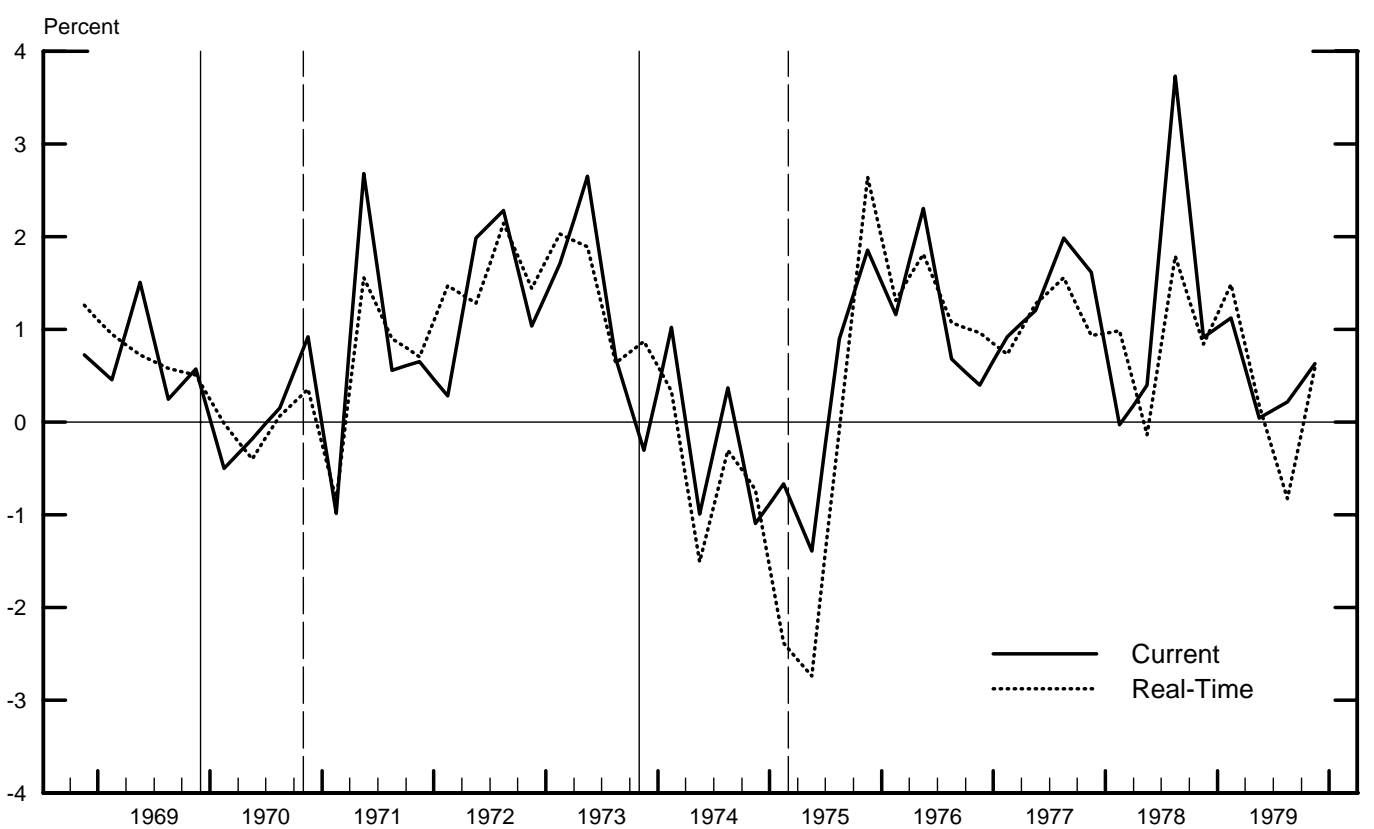

Cumulative Discrepancy in Real Output Levels

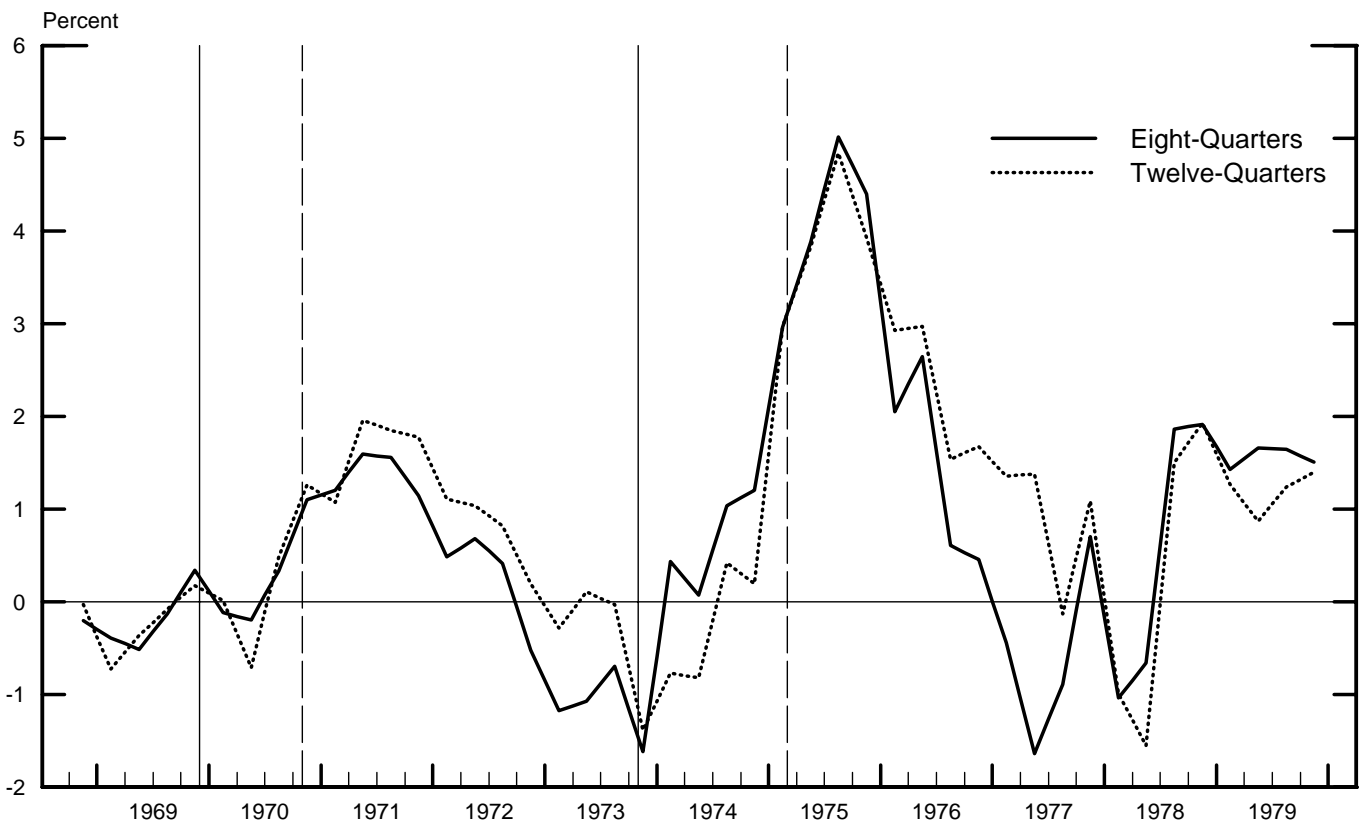

Notes: Real output growth is the quarterly change in real output for quarter $t-1$, in percent. The cumulative discrepancies show the difference in estimates of real output growth between current and real-time data over the horizons shown ending in quarter $t-1$, in percent. See also notes to figures 1 and 2 . 
Figure 5

\section{The Economic Outlook at the August 1970 FOMC Meeting}

\section{Inflation}
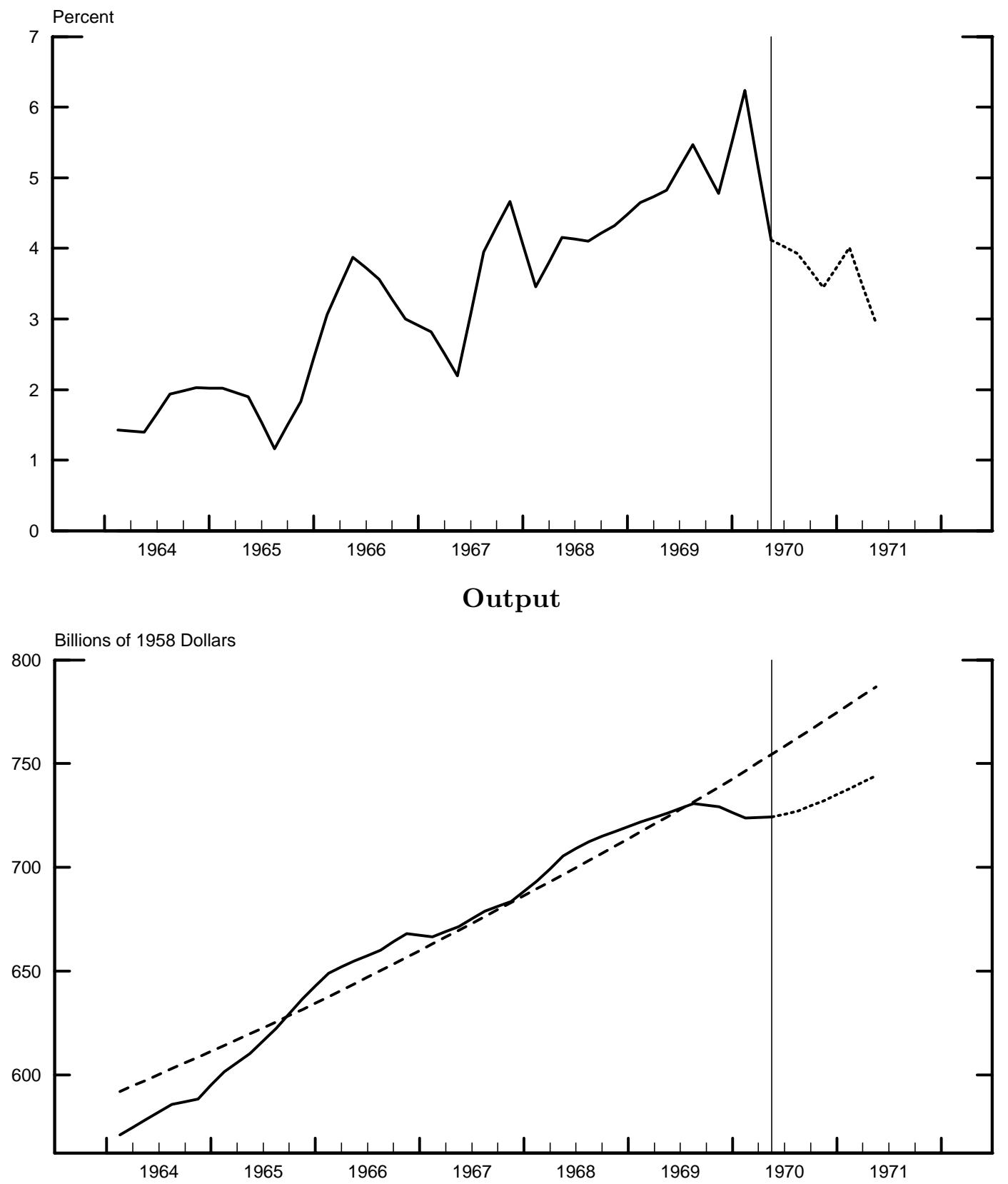

Notes: Inflation is the log change in the output deflator from the previous quarter, in percent annual rate. Output is actual GNP (solid line) and the official estimate of potential GNP (dashed line) for the quarter shown, measured in an annual rate with constant 1958 dollars. The vertical line in 1970Q2 indicates the last quarter of historical data. The dotted lines represent Greenbook forecasts. 


\section{CFS Working Paper Series:}

\begin{tabular}{lll} 
No. & Author(s) & Title \\
\hline $2002 / 05$ & Bernd Kaltenhäuser & $\begin{array}{l}\text { Return and Volatility Spillovers to Industry } \\
\text { Returns: Does EMU Play a Role? }\end{array}$ \\
$2002 / 06$ & Erik Theissen & $\begin{array}{l}\text { Internalisierung und Marktqualität: } \\
\text { Was bringt Xetra Best? }\end{array}$ \\
& $\begin{array}{l}\text { Werner Neus } \\
\text { Uwe Walz }\end{array}$ & $\begin{array}{l}\text { Exit Timing of Venture Capitalists in the Course } \\
\text { of an Initial Public Offering }\end{array}$ \\
& $\begin{array}{l}\text { Andreas Bascha } \\
\text { Uwe Walz }\end{array}$ & $\begin{array}{l}\text { Financing Practices in the German Venture } \\
\text { Capital Industry } \\
\text { An Empirical Assessment }\end{array}$ \\
& & The Credibility of Central Bank Announcements
\end{tabular}

$\begin{array}{ll}\text { 2002/10 } & \text { Markus Haas } \\ & \text { Stefan Mittnik } \\ & \text { Marc S. Paolella }\end{array}$

2002/11 Elke Hahn

2002/12 Yunus Aksoy

Hanno Lustig

2002/13 Andreas A. Jobst

2002/14 Andreas A. Jobst

2002/15 Athanasios Orphanides
Mixed Normal Conditional Heteroskedasticity

Core Inflation in the Euro Area:

An Application of the

Generalized Dynamic Factor Model

On the Short and Long Term Real Effects of

Nominal Exchange Rates

Collateralised Loan Obligations (CLOs) A Primer

The Pricing Puzzle: The Default Term Structure of Collateralised Loan Obligations

Activist Stabilization Policy and Inflation:

The Taylor Rule in the 1970s

Copies of working papers are available at the Center for Financial Studies or can be downloaded (http://www.ifk-cfs.de). 